\title{
Promoting Literature to Build College Students' Socio-political Awareness in the EFL Reading Class
}

\author{
Dian Nurrachman \\ UIN Sunan Gunung Djati Bandung \\ diannurrachman@yahoo.com
}

\begin{abstract}
The relationship of classroom to the outside world is a reciprocal one, meaning that classrooms are part of the world in which socio-politics is included. The students become successful literary readers as well as critical thinkers who have socio-political awareness if the classroom conducts an 'extensive reading' by 'letting the students in'. The implication of these understandings for the work of EFL teachers is to give a vindication that literature can fully become the best authentic material in the teaching and learning of English, especially for reading class of the college students. In certain ways, this is also aimed to promote literature as a device to build students' socio-political awareness, because literature, we are told, is vitally engaged with the living situations of men and women: it's concrete rather than abstract, displays life in all its rich variousness.
\end{abstract}

Key words: socio-political awareness, literature, reading class

Teaching and learning English are always interesting for some people. This interest is quite logical; for English certainly tends to be the most popular language in the world. It becomes the number one international language used by people from any countries in the world to communicate. Therefore the main concern in the teaching and learning of English, especially in the EFL (English as a Foreign Language) context, is to help students acquire the communicative competence. However, for this reason indeed, we tend to focus on what usually people think about language classroom, of language teaching and learning, which is often in terms of new methods, strategies, grammar, tasks, exercises, language drills, or in short, the activities of teaching and learning linguistic expression. This perspective also tends to see the classroom as something of a closed box; that is, "an educational context separated from society" (Pennycook, 2000:89). This is quite dangerous, because education actually produces not only knowledge but also political subjects, thus suggesting that Teaching English as a Foreign Language (TEFL) should transform students into political society and giving awareness of the partial and particular versions of knowledge, truth, and reason (Alwasilah, 2001:43).

In light of this concern, Pennycook (2000:91) suggests, by contrast with a closed box perspective, that "classrooms are sociopolitical spaces that exist in a complex relationship to the world outside". He explains that the term political is used not to suggest a formal domain of politics, but rather to address the questions of social and cultural relations from a critical perspective (Pennycook, 2000:91). He also adds that such a perspective 
concerns on making critical interpretations and suggesting possible alternatives (Pennycook, 2000:91). This perspective is actually related directly to one of the objectives of studying English in Indonesia which is issued by Pusat Kurikulum Balitbang Depdiknas (2002:6), that is, "Developing comprehension about the relation between language and culture then enlarging culture horizon. By so doing, the students are able to understand cross-culture and involve themselves in the varieties". In this sense, "enlarging culture horizon" can be interpreted as making connection to the broader sense of culture, including what Pennycook believes as "socio-political" spaces. Therefore, through this perspective, here I would like to promote literature as a device to build college students' socio-political awareness, especially in the EFL college reading classroom.

\section{Some Questions}

But why is literature actually? As a matter of fact, the reasons are vary. Palardy (in YuhMei Chen, 2006) states that through literature, student readers "will have the opportunity to develop insights and understandings of the cultures and people of the world; to develop their imagery and visualization abilities; and to gain new perspectives by testing their ideas with those found in books". Likewise, Root (in Yuh-Mei Chen, 2006) maintains that literature helps the readers better understand themselves, their world, and the aesthetic values of the written text. Alwasilah (2001:38) also emphasizes that "by reading literary works, students share the problems, concerns, values, and issues common to all human beings. Thus, those reasons are actually having the same concern; the importance of literature in the EFL classroom.

Another question will be pointed to reading classroom. Why should I propose such? This is because the very nature of literature (literature as text/work) is a reading subject. Here I follow Louise Rosenblatt's division of the reading text: first efferent reading and second aesthetic reading (in Chamblee, 2003:272). Efferent reading refers to the reading of factual information and then responding with a specific answer (Chamblee, 2003:272). We know that many college reading classes have taken this stance toward reading. In this skills-type approach, vocabulary is pre-taught and then comprehension questions are asked (Chamblee, 2003:272). Meanwhile, the aesthetic reading refers to a different type of reading. It consists of reading with attention to what readers are experiencing, thinking, and feeling (Alwasilah, 2001:35). This type of reading is actually a literature one, because as Rosenblatt (in Cox, 1996:237) maintains that for most experiences with literature, "our primary responsibility is to encourage the aesthetic stance".

However, I don't think that Rosenblatt's ideas will cease only to the reading activities without any connections to social environment which surrounds the reader. The discussion of literature demands consideration of the mind of the individual reader or groups of readers. It requires us "to see the reading act as an event involving a particular individual and a particular text, happening at a particular time, under particular circumstances, in a particular social and cultural setting, and as part of the ongoing life of the individual and the group" (Rosenblatt in Probst, 1987). So to speak, reading literature as an aesthetic stance will also cover such particular circumstances, including socio-politics area as reflected in literature itself. In this sense, I agree with Eagleton (1996:20) that literature "has the most intimate relation to questions of social power". Since the "social power" is part of socio-politics area, then it is clearly now that reading class is suitable for promoting literature as a device to build students' sociopolitical awareness.

What kind of literature can evoke students to build their socio-political awareness? Basically, all of literary genres, i.e. prose, poetry, and drama can be devices for such efforts. The important thing is put upon our selection to 
the works themselves. In prose, as well as in poetry and drama, there are so many works which explore social, cultural, political, and ideological themes. In the literary canon (the great tradition) of English literature, such themes are the commonest besides love and sexuality. We can see that William Shakespeare, John Milton, William Wordsworth, Jane Austen, Charles Dickens, Rudyard Kipling, and Joseph Conrad - to mention only several names - are those whose works explore social, cultural, political, and ideological themes. Even, in considering the political awareness in literature (especially to make a general depiction in the past of $19^{\text {th }}$ century English imperialism), Eagleton (1996:23) says that "if you do not have the money and leisure to visit the Far East, then you can always 'experience' it at second hand by reading Conrad or Kipling". So to speak, literature has a potential to evoke readers not only as a blissful aesthetic reading but also social, cultural, and political experience.

So do Shakespeare's, Milton's, Wordsworth's, Austen's, and Dickens' works. They produced various themes in terms of social, cultural, political, and ideological experience. In Shakespeare's dramas, we can find the intriguing socio-political context of betrayal, power struggle, war, etc. from the characters ideology. In Milton's poems, we can see how Christian reform contributed English sociopolitical context at the time. From Wordsworth's poems, we are given the awareness of how do natural settings contribute to explain our social and even political behavior. Austen's novels are undoubtedly took the real settings of middle class family at the time and give us many things related to the English middle class; how they behaved, what things to prepare marriage, the essence of dating and dancing, religious performances, and so forth. Meanwhile, Dicken's novels play a role in constructing socio-political awareness in terms of loyalty, friendship, betrayal, power struggle, and so forth. Those instances-and actually we can add more-are the authentic texts which enable to be posited in the EFL college reading class to build students' socio-political awareness. For this reason of authenticity, Cox (1996:265) then argues that "Integrated teaching with literature is natural in whole-language classrooms, in which authentic texts....... are the true texts used".

To make the teaching of reading (literary reading) becomes powerfully integrated with socio-politics area, the question might be asked, then, is how to succeed students as readers to build their critical thinking and socio-political awareness in the classroom? Since I believe that the relationship of classroom to the outside world is a reciprocal one, meaning that classrooms are part of the world in which socio-politics is included, so the very ways we run classes need to be seen in terms of such socio-politics itself. In line with this, Pennycook (2000:98) suggests, "Once we start to understand that cultural politics happen not only in the classroom and the world but also, inevitably, in the heads of our students, then, we have to see classrooms as sites where identities are produced and changed". He continues that "we need to understand that these identities are multiple and shifting and tied to language and language learning" (Pennycook, 2000:98), especially in the context of reading as one of language learning. This is because students as the readers could hardly deny the contextual meanings and intentions (including the socio-political subjects) inside the reading texts, which are potentially able to leave influences and/or objections in their minds as the primary sources to build critical thinking as well as socio-political awareness.

\section{Roles of Extensive Reading}

In this context, the students will become successful literary readers who have critical thinking as well as socio-political awareness if the classroom is conducted by 'extensive reading' strategy. The strategy of extensive reading is important to be conducted in read- 
ing class since "the best way for students to learn to read is by reading a great deal of comprehensible material" (Day in Hedgcock and Ferris, 2009:206). The extensive reading's goal is therefore a comprehension of main ideas, not every detail or word (Aeberson and Field in Hedgcock and Ferris, 2009:207). This kind of strategy also means that teachers should allow students to create their own comprehension tasks. By this strategy, students can share ideas freely in identifying, producing, changing, or even countering their own identities and awareness to what they read (the particular contexts and intentions) on reading texts, in this sense, literature. Different points of view in discussing the topics are necessarily required as well, for it may lead to sharpened literature as a device in understanding ourselves and our society, as well as building our socio-political awareness. So now here, I will insert an example of discussion to make this kind of teaching and learning invaluable and applicable in the EFL reading class. The work that I would like to engage here is a poem by May Swenson, entitled "Women should be pedestals", cited from DiYanni (1986:722).

\section{Women Should be Pedestals}

Women should be pedestals

moving pedestals

moving to the motions of men

Or they should be little horses

those wooden sweet oldfashioned painted

rocking horses

the gladdest things in the toyroom

The pegs of their ears so familiar and dear to the trusting fists

To be chafed feelingly

and then unfeelingly

To be joyfully ridden

until the restored egos dismount and the legs stride away

immobile sweetlipped sturdy and smiling women should always be waiting willing to be set out into motion

Women should be pedestals to men

\section{Teaching Route}

In the teaching of reading, one main important activity to be included for bridging the gap between textual materials and students (as readers) is to arouse students' background knowledge first. This is because they bring prior "information, knowledge, emotion, experience, and culture to the printed word" (Brown, 2001:299). So does literary texts (in this case, a poem) as well. Teacher should fully understand to what students know previously about the authentic text and the topic that will be discussed. Since the focus of 'reading' itself is to comprehend the meaning, so the knowledge about the topic and how English works play an important part in enabling us to predict the meaning(s) itself. Here, the first knowledge that should get across is about "women". The teacher has to be able to create the questions and/or opinions creatively to arouse students' background knowledge as well as their critical thinking on the subject of "women". For instance, teacher can ask: "Are women only created to be angel in the house? Why? Since they are also human that live in particular social and political context, so are they playing important role in broader life?" and so forth. Teacher also can give his/her own opinions and/or give other's opinion, for instance: "My own definition of woman is very simple: it rests on the word 'man'..." (Spivak, 1986). So, what do you think about this statement?" and so forth. In turn, those questions/opinions are intended to lead students for the first time to build the socio-political awareness dealing with what the text will come into their mind.

Thus, after having some 'warming up' in terms of students' background knowledge as well as their critical thinking on the topic to be discussed, the teacher can distribute the text, i.e. a poem above by May Swenson entitled "Women should be pedestals", and 'let the students in' to the text first (the time conducted can be vary, depending on each student's level of comprehension). This activity will be 
successful if, as Harmer (2007:288) suggests, the students are allowed to create their own comprehension tasks. Since the text given is poetic text, so the students have to be able to build their comprehensive critical thinking in terms of socio-political awareness on 'women' based on the poetic elements, among others: dictions, figures of speech, imagery, symbolism, and so forth. Those poetic elements will help students to acquire the poem's meaning and relate it to the broader senses: social, cultural, political, historical and ideological context. By and by, the teacher can make students to sit in group, and let them discuss what have actually come into their minds. In the main session, each group can present (in short time) their findings from the text given related to the topic of "women" and discuss them with the teacher together.

In the final session, then, we can do a reflection to what has been discussed so far. The results of such reflection and discussion might be greater knowledge of self, of the text, and of the others with whom the student talks. This is what I personally call "self awareness" which basically derived from critical thinking. In the case of the poetic text given entitled "Women should be pedestals", so I can infer some reflections here, that: "there are many women, in any societies, who are still facing violence (To be chafed feelingly/and then unfeelingly); there are many women, in any societies, whose political rights are still steering, or even carried away (women should always be waiting/willing to be set into motion); and there are many women, in any societies, who are still inferior to men (Women should be pedestals to men)". In so doing, such reflections can become the starting point for students to build their own socio-political awareness based on their reading to the poem, or any works of literature.

A series of activities above should fully be based on the cooperative atmosphere of the classroom. If students are to deal with these matters, many of which will be personal; the reading classroom in which literature become the authentic resources/materials must be cooperative rather than combative. Debatewhere one wins and one loses, one is right and the other wrong - is not an appropriate model for most discussion of literature, moreover, if our teaching purpose is to build some critical awareness. In cooperative atmosphere, "discussions should encourage students not to win but to clarify and refine; they are encouraged to enter into a 'reciprocal, mutually defining relationship' in their discussions with students and teachers, as well as in their readings of texts" (Probst, 1987).

To have concluding remarks, I would like to examine what we have uncovered so far. But before I go through, I also would like to quote some lines from a poem by a wellknown Indonesian poet, the late W. S. Rendra (Almarhum), entitled "Sajak Sebatang Lisong" (1980:30). These following lines are important to lift up, because they have a direct relationship with my discussion here.

Aku bertanya,
tetapi pertanyaan-pertanyaanku
membentur meja kekuasaan yang macet
dan papan tulis-papan tulis para pendidik
yang terlepas dari persoalan kehidupan

Those lines above suggest that schools, classrooms, methods, syllabus content, and so on (papan tulis-papan tulis para pendidik), often hardly touched the real life problems (terlepas dari persoalan kehidupan). The result is that students are often unaware with anything related to such real life problems, and tend to reject their surroundings. This is ironic, since education is to help people to be more human, to be more realistic, and to be more care with others, and classrooms are the places where students should become transformative intellectuals. Therefore, in the very beginning of this essay, I intentionally took Pennycook's ideas to justify what I wanted to propose and discuss within. I do agree with him that class- 
rooms are socio-political spaces that exist in a complex relationship to the world outside. We could not avoid that we are part of complex social, economic, and political relations that flow back and forth through our classroom walls. To say the jargon coming from The X-Files movie series: "The truth is out there", and therefore, the teachers' job are to take "the truth", which is 'outside classroom' to be involved 'inside classroom'. The teaching and learning of English, especially in our Indonesian EFL context, thus, must be based on this perspective.

As a matter of fact, this is not an easy job, since there are many impediments in our English classroom related to the language skills and components themselves. However, besides communicative competence which based on linguistic competence, we also need to develop cultural competence in which social, political, and ideological contents are included. So, we need to understand the roots of this cultural competence based on the very basic stance, that is, literature. In this context, both the study of literature and literature as resource are used equally, since I proposed this for and in the EFL aesthetic reading class.

\section{CONCLUSION}

By combining the transactional view on reading developed by Louise Rosenblatt and the theoretical stance on socio-politics in English teaching developed by Alastair Pennycook, I would like to show and promote that reading literature can arouse our socio-political awareness, otherwise. The important things to be conducted are the treatments themselves, including material's selection, activating students' background knowledge, making connections between text and context by silent reading (individually), group discussion and presentation, until making some reflections to examine what we have done and making interrelations to the purpose of building socio-political awareness itself. This is worthwhile to be conducted by any EFL teachers, especially for college reading class, since adult learners should be treated differently from the young one. And literature, I think, is the most authentic resource/material to be posited (in its portion) in and for the language classroom. 


\section{REFERENCES}

Alwasilah, A. C. (2001). Language, Culture, and Education: A Portrait of Contemporary Indonesia. Bandung: CV. Andira.

Brown, H. D. (2001). Teaching by Principles: An Interactive Approach to Language Pedagogy. New York: Addison Wesley Longman, Inc.

Chamblee, C. (2003). Reader Response in the College Reading Class. In Eric J. Paulson et al (Eds). 2003. College Reading Research and Practice: Articles from The Journal of College Literacy and Learning. Delaware: International Reading Association. (pp. 271-279).

Chen, Yuh-Mei. (2006). Using Children's Literature for Reading and Writing Stories. Asian EFL Journals: The EFL Professionals Written Forum. (Electronic version, Volume 8, Issue 4, Article 9), accessed on May 3, 2009.

Cox, C. (1996). Teaching Language Arts. Boston: Allyn and Bacon.

Depdiknas. (2002). Kurikulum dan Hasil Belajar: Kompetensi Dasar Mata Pelajaran Bahasa Inggris. Jakarta: Pusat Kurikulum Balitbang Depdiknas.

Eagleton, T. (1996). Literary Theory: An Introduction ( $2^{\text {nd }}$ Edition). Oxford: Blackwell Publishers Ltd.
Harmer, J. (2007). The Practice of English Language Teaching. Edinburgh: Pearson Education Limited.

Hedgcock, John S. \& Ferris, Dana R. (2009). Teaching Readers of English: Students, Texts, Contexts. New York: Routledge.

Pennycook, A.. (2000). The Social Politics and the Cultural Politics of Language Classroom. In Joan Kelly Hall and William G. Eggington (Eds). 2000. The Sociopolitics of English Language Teaching. Clevedon: Multilingual Matters. (pp. 89-103).

Probst, R. E. (1987). Transactional Theory in the Teaching of Literature. ERIC Digest. ERIC Clearinghouse on Reading and Communication Skills Urbana IL, accessed on April 12, 2009.

Rendra, W.S. (1980). Sajak Sebatang Lisong. Potret Pembangunan dalam Puisi. Jakarta: Lembaga Studi Pembangunan

Svipak, G. C. (1986). Feminism and Critical Theory. In Robert Con Davis and Ronald Schleifer (Eds). 1996. Contemporary Literary Criticism: Literary and Cultural Studies. New York: Longman. (pp. 519-534).

Swenson, M. Women should be Pedestals. In Robert DiYanni. (1986). Literature: Reading Fiction, Poetry, Drama, and the Essay. New York: Random House. 
